\title{
The Implementation of Portfolio Assessment in Japanese Learning at Senior High School
}

\author{
Lusi Asmaraningtyas ${ }^{1, *}$ Miftachul Amri ${ }^{1}$ Syamsul Sodiq ${ }^{2}$ \\ ${ }^{1,2}$ Education of Language and Literature, Universitas Negeri Surabaya, Indonesia \\ *Corresponding author: lusi.20046@mhs.unesa.ac.id
}

\begin{abstract}
During distance learning in the middle of the Covid-19 pandemic, the e-portfolio assessment can be preferred as an alternative to other assessments. The purpose of this study is to find out; 1) how the implementation of e-portfolio in Japanese language teaching in SMAN 5 Malang is, 2) how to analyze the appearance of difficulties in collecting students' works during the Covid-19 pandemic. This study used the observation method and descriptive qualitative approach to describe the implementation of the e-portfolio and break down the obstacles that appear along the process. The participants are the students who were studying Japanese in SMAN 5 Malang. The result shows that during online learning, students' works were collected through online platforms, namely Whatsapp, Google Classroom, and Flipgrid. Those three applications were the primary preference because they are easy, simple, and internet data-friendly. However, difficulties still appear from both sides of teachers and students. The teachers face the challenge in the process of assessing students' inactiveness when collecting their works. Meanwhile, the students have to deal with the connection problem, inability to use the application, system error during the assignment submission, etc.
\end{abstract}

Keywords: E-portfolio, Online, Online platform.

\section{INTRODUCTION}

In the process of teaching and learning during the Covid-19 pandemic has occurred several problems, especially in the process of assessment. There is a need for an alternative plan to support the effective and efficient process of assessment. One of the alternatives which can be considered is the online portfolio assessment. Akhmad Muzakki (The Chairman of the East Java Education Council) said that a portfolio could be used as one of the solutions to decide the students' achievement because it can be used maximally to see the creativity and innovation of the students. Furthermore, Muzakki stated that a portfolio allows the students to have self-reflection, evaluating how far they can learn about themselves as a thinker and developing the ability in particular events. Portfolio assessment as the alternative during online learning shows the students' affective, cognitive, and psychomotor aspects. Moreover, it is not only cognitive assessment that is needed but also how they can solve the problem in the current situation [1].

The portfolio comes from two words: port (abbreviation of the report), which means report, and folio, which means complete. Hence, a portfolio means a complete report of all the activities by an individual. According to Asrul [2], portfolio assessment is an evaluation by collecting important documents or archives arranged in the form of bindings in certain kinds of works. A portfolio focuses on collecting students' results to show their progress in a period of time. This is in line with what has been stated by Asrijanti [3] that a portfolio is a compilation of students' works from their study experience during a certain period. This collection includes all kinds of active participation in selecting content, criteria of the selection, criteria of the assessment, and self-reflection proof. According to Mertler [4], a portfolio assessment is a set of organized student works that can be used to depict the effort, progress, or achievement. Meanwhile, the definition of an electronic portfolio (e-portfolio) is as what has been quoted by Muenthaisong [5]:

E-portfolios are considered a useful pedagogical tool for assessment to facilitate the adoption of more learner-centered practices. They are seen as a powerful education tool for empowering students' responsibility for their learning. (Paulson, Paulson, and Meyer (1991) 
Based on the definition, e-portfolio is seen as a pedagogic tool that is useful to evaluate and facilitate the practical implementation which focuses on the students and seen as a powerful learning tool to authorize students' responsibility or their learning. Moreover, a portfolio allows students to have full control of their learning in many ways, which some other instructional approaches allow. This experience could motivate the students to be more involved. The steps of designing a portfolio according to Daryanto \& Amirono are 1) decide the portfolio material, that is in the process the teacher involved the students through a discussion process to achieve mutual agreement, 2) set the final submission time, 3) determine ways to submit and arranged it, 4) decide where and how the portfolios are stored [6].

The previous study about portfolio assessment during the pandemic was done by Ana \& Ndole [7] related to "The effectiveness of Mathematic Assessment During the Pandemic of Covid-19 in SDK Ndona 2 District Ndona, Ende Regency". It showed that portfolio assessment is practical but only in cognitive aspects, while affective and psychometric aspects cannot be covered. The reason is that the teacher can only assess the result of the portfolio from each student. Another study by Ahmad [8] is about "Alternative Assessment in Distance Learning during the Emergency Moment of Coronavirus Disease (Covid-19) Spread in Indonesia". It used the Library Research method and discovered that during the Covid19 pandemic some types of assessments could be implemented during distance learning: online-based assessment, portfolio assessment, and self-assessment. Portfolio assessment seems to be one of the best alternative assessments chosen by teachers in Indonesia and overseas, for example, in China. Cheng Shu [9] studied the E-portfolio assessment utilized as final assessments to students for an online graduate course during the COVID-19 pandemic at Jiangsu Normal University in Mainland China. Students created Eportfolios according to learning goals with different aspects of the course. The purpose of this study was to assess and analyze students' reflections on those aspects. Through PowerPoint and other presentation software, the student was asked to provide these questions: 1) Who are you, 2) What are your learning goals for this course? 3) What have you done for this course? 4) How did you learn what you want to learn? 5) What is your favorite subject in this course? 6) Others (anything else you want to show me your learning achievements). Despite the original design of e-portfolio for final assessments to students, they were, in return, final assessments for the course and the teacher.

The government's mandatory social distancing and physical distancing have limited the interaction between teachers and students. Therefore, there is a need for appropriate media to collect students' works. Teachers mostly choose online media to accommodate students' assignments submission. With the advance of technology development nowadays, the implementation of distance assessment has made it possible and easy, especially by using an internet connection. The advantages of online media are its wide range of networks, easy to use, no need to be installed, and free. Those aspects are the main consideration by the teachers. Thus the students and the parents do not overwhelm by the distance learning process.

This study was conducted in SMA Negeri 5 Malang. The purpose is that the school has implemented concrete steps for an effective distance learning process by urging and giving special training for the teachers to introduce many online applications to be used during the study from home. One of them is virtual media using Zoom or Google Meet, assignment submission media using Google Classroom or Edmodo, teaching and learning evaluation media using Google Form or Quizizz. There is no one particular platform to be used because the choices are accessible for the teachers based on their convenience in teaching. Based on the unstructured observation and the interview Whatsapp is the application preferred by most teachers (chat service and video call). It is because the familiarity and is widely used. Besides, other applications are also popular among teachers. Those are Zoom, Google Classroom, Google Form, and Quizizz. In Japanese language teaching and learning, the teacher also used an online platform to collect students' works: Whatsapp, Google Classroom, Google Drive, and Google Form to collect students' written assignments. In contrast, Flipgrid is used to submit oral assignments in the form of video. Japanese language teaching in SMA Negeri 5 Malang during the distance learning is conducted once a week for sixty minutes. It is done synchronously and asynchronously with the regulation of virtual meetings once every two weeks. During the even semester, there are eighteen weeks of the active meeting. The assignments are given regularly every meeting with fewer burdens as part of the exercising process. The assessment for knowledge and skill is done alternately based on the basic competence due to the shortened teaching period from $3 \times 45$ minutes to 2 x30 minutes.

Based on the explanation above, a case study is conducted to find out:

1. How the implementation of e-portfolio assessment in Japanese language teaching in SMAN 5 Malang is,

2. How to analyze the appearance of difficulties in collecting students' works during the Covid-19 pandemic.

\section{METHODS}

This study is a descriptive qualitative study to describe the implementation of portfolio assessment in the Japanese language teaching in SMAN 5 Malang and analyze the appearance obstacles in students' work 
submission during the pandemic of Covid-19. The object of this study was Japanese teacher documentation of students' works collection during the even semester, which is used to answer the first research question. Meanwhile, the procedure to answer the second research questions are 1) developing the questions for the questionnaire, 2) spreading the questionnaire for the students of grades $\mathrm{X}$ and XI. The questionnaire was distributed to 138 students; there were 114 respondents, 3) analyzing the questionnaire, 4) concluding the result. The questionnaire will be distributed through Google Form, which has four questions with a checklist and essay responses. Those questions are regarding what media teachers use in collecting assignments and the advantages and disadvantages of collecting tasks with Whatsapp, Google Form, and Flipgrid.

\section{RESULTS AND DISCUSSION}

\subsection{The Implementation of Portfolio Assessment in SMAN 5 Malang}

During the teacher and learning, the teacher used some of the applications and platforms above to collect students' assignments or works. The portfolio was not collected in the form of paper. However, based on the observation, the Indonesian and physics education used a paper-based portfolio. Regularly, the students were asked to come and submit their works. However, the data collected from the questionnaire mentioned by the students were using online media as provided by the data below:

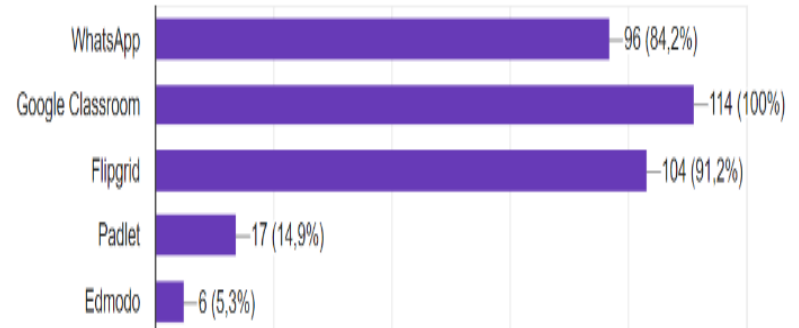

Figure 1 The result of the questionnaire

Based on the graph above, it can be concluded that Google Classroom is used mainly as an online medium to collect students' works. It can be assumed that Google Classroom has more advantages than the others. It can be concluded from the result of the questionnaire as follows:
a. easier
b. simple
c. private
d. well-organized
e. deadline setting availability
f. reminder and notification provided
g. stored and secured in Google Drive
h. easy to track the working progress
i. big file storage
j. $\quad$ easy to be submitted and categorized

\subsection{Portfolio using Google Platform}

Google Classroom and Google Forms have been compulsory platforms for teachers during the pandemic. Google Classroom is one of the applications developed by Google, which is helpful for teaching during distance learning. There are many other applications provided by Google which can be used to teach. The advantages of Google Classroom focus on learning and assessment. The exciting layout, practice, and complete features (can save word and PDF files) are integrated with other applications such as YouTube. Two ways of communications can be done, the data are stored neatly in Google Drive in the form of Cloud, so there are no worries of losing the data. The data stored in Google Drive can be sorted based on timeline and accessed at any time. Another advantage is that the student's work can be scored and assessed right away as the feedback from the teacher. Besides, there is a notification when students or teachers update their activities (announcements or submission of the assignments) and a reminder of the due date.

Google Form is helpful to create or send surveys, plan an event, make and send quizzes or tests as part of the exercises. Google form also can be used to collect information quickly and efficiently. The benefits of Google Form are easy to use, free, less internet data use, easy to share, and automatic spreadsheet feature, which is helpful to collect survey results.

Here are some of the portfolio examples by the students by using Google Classroom and Google Form:

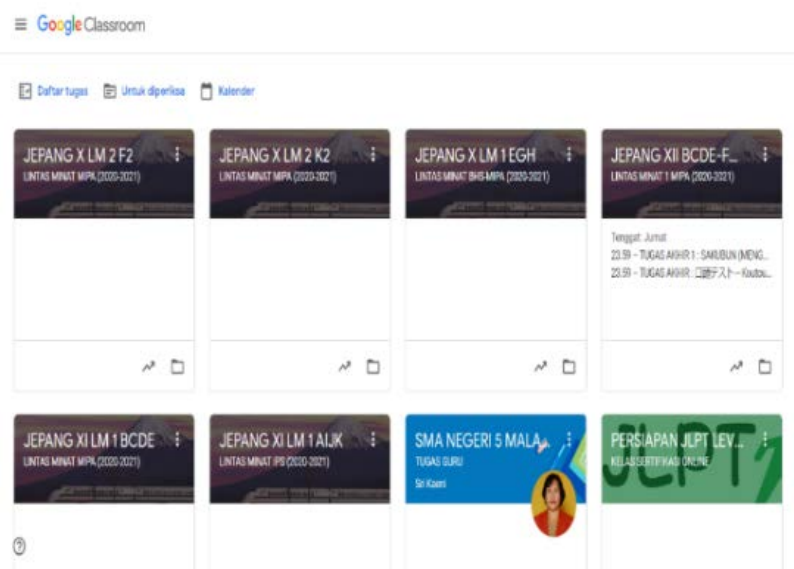

Figure 2 The Front Display of Google Classroom 

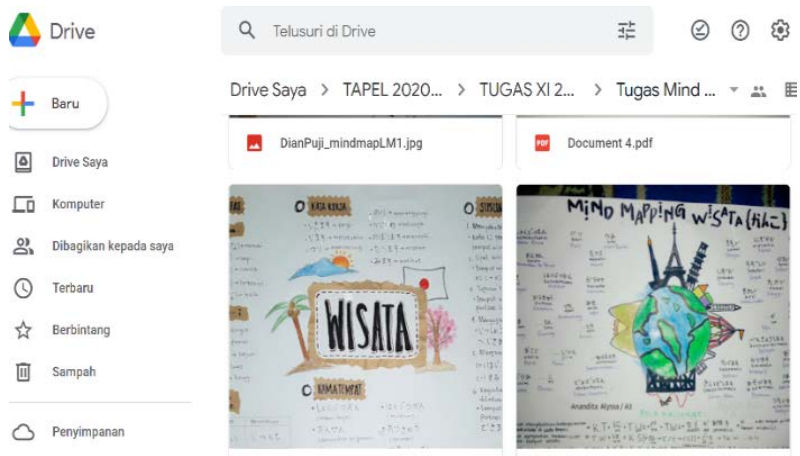

Figure 3 The appearance of the Mind-Mapping assignment from Grade XI

Overall, many students have completed the assignments. The obstacles commonly faced related to the assignment submission in Google Classroom is that many students still submit the assignment overtime or even do not submit it at all. They make many reasons such as the abundance of assignments from other subjects and forget between one assignment to another. Furthermore, many students copy-paste their students' works. It influences the assessment process, which does not meet the expectation. The validity is the problem in this case.

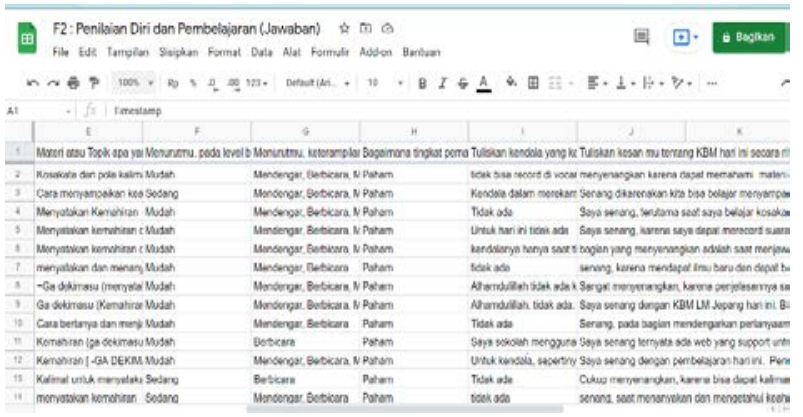

Figure 4 Students' Self-Reflection

The teacher assigned the self-assessment after the teaching and learning process. The result is presented globally during the Whatsapp group's virtual meeting as a reward or feedback for the students to their upcoming lesson. However, based on the observation, the students' activeness was varied. At one time, many students filled the self-assessment form; in another time, only $5 \%$ of the students did it. It should be the task of the teacher to find out the solution.

\subsubsection{Portfolio Using Whatsapp Group}

Another media used is Whatsapp via private chat or group chat. The advantages of this application are familiar, easy, and quick two ways of communication (chat, phone call, or video call). The feature in Whatsapp is complete enough to collect various types of written documents, videos, and audio. However, it lacks the timeline track record. It supports the assignments' submission. Another disadvantage is that the students' assignments can be easily forgotten and ignored due to the stack of messages, so the teacher was no longer aware of the projects. Here are the assignments of portfolio assessment via Whatsapp:

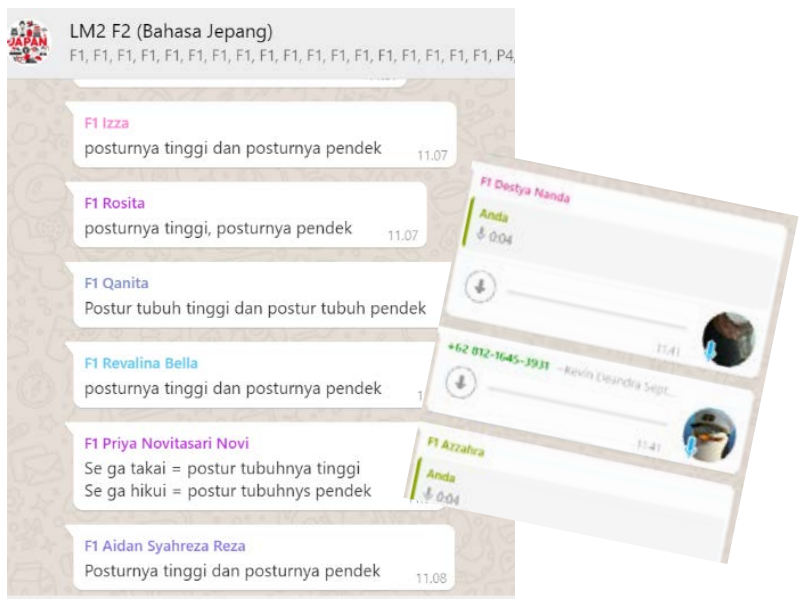

Figure 5 Assignments’ submission via Whatsapp

\subsubsection{Portfolio using Flipgrid}

Flipgrid is an application developed by Microsoft used by the students to respond in the form of a video from the topic or teaching material provided by the teacher. In language teaching, it is useful, especially for speaking sill as one of the required skills. In FlipGrid, all students have the same chance to answer or respond in video as creatively as possible. The other positive things about this application are free, no need to be installed, and easy to use because the teacher can directly provide feedback and response in the application. It also does not need big storage in their devices because it is connected and saved in Cloud. Moreover, it helps the teacher to collect students' responses on one topic. The teacher and the other students also enjoy the videos by setting the comment section "Online" to give comments of feedback to their friends' videos. Therefore, the teachers can see the interaction among students. The assessment can be done by setting the criteria first. However, based on the observation the difficulties the problem with the implementation was that some students were still unable to operate the application efficiently because of the unsupported system. The solution was that the teacher asked the students to submit the assignments in another application manually, Whatsapp.

\subsection{The Obstacles of the Students' Works Submission Process}

In the questionnaire, which was distributed to 138 students, there were 114 respondents. Here are the difficulties of each online application during Japanese language teaching.

(1) Whatsapp

a. Often stacked with other messages 

b. Only has $64 \mathrm{Mb}$ (cannot send bigger files)
c. Easy to lose the data
d. Impractical, some errors will lose the data
e. Easy to forget due to no reminder
f. Limited time storage
g. Unorganized
h. The quality of photos are reduced

(2) Google Classroom
a. System error often happened
b. Unable to send bigger video resolution
c. File submission takes time
d. Getting complicated when there are too many files
e. Limited capacity and some files should be uploaded in Google Drive first
f. The submission pressing button is not easy sometimes
g. Connection problem

(3) Flipgrid
a. Confusing
b. Unable to submit the assignment over time, unlike G-Class or Whatsapp
c. Not cellphone friendly, video edited by other applications should be uploaded via computers
d. Suspicious. There is no notification of whether the assignment has been submitted or not.
e. Assignments can be seen by other classmates (shy)
f. Unable to export the video from cell phone's gallery, it should be from Flipgrid.
g. Complicated
h. Require more internet data package
i. There is a video submission time feature. The sound often changes when the duration of the video is longer. Sometimes not easy to upload the video.

Those are the difficulties experienced by the students while using the applications. Among the three applications mentioned above, Flipgrid is the most complicated one. It is because there are not many teachers yet using the application. Therefore, students face many difficulties during the submission. Meanwhile, students have been familiar with using Whatsapp and Google Classroom to solve their technical problems.

On the other side, using these three applications, especially the Flipgrid Application, is one alternative that can be offered to assess students' knowledge and skills. Thus, previous research which states that portfolio assessment is difficult to assess students' psychomotor abilities can be resolved.

\section{CONCLUSION}

The pandemic has changed many aspects of life and the educational sector: teaching and learning and assessment. However, those changes are not all negative. We need to start adjusting to new ways of life to gain positive things from the difficulties we face now. Assessment is as critical as teaching and learning. Authentic assessment is a must during the teaching and learning process. One kind of authentic assessment is portfolio assessment. It is called authentic because a portfolio collects evidence of students' active involvement during teaching and learning. The teachers can use the proof to monitor their knowledge, skill, and attitude development in a particular subject. During the study from home, the implementation of portfolio assessment in SMA Negeri 5 Malang, students' work submission was collected using the online platform, namely Whatsapp, Google Classroom, and Flipgrid. They are the main preference because they are easy, simple, and have low internet data costs. The use of these three applications, especially the Flipgrid Application, is one alternative that can be offered to assess students' knowledge and skills. Thus, previous research which states that portfolio assessment is difficult to assess students' psychomotor abilities can be resolved.

However, in using applications that are not too familiar, there are many difficulties encountered. Nevertheless, the challenges appear from the teachers and students. The teachers assess students' inactiveness when submitting the assignment is one of the challenges faced by the teachers. Meanwhile, the students had a connection problem, were incapable of using the applications, assignment submission system error, many assignments that were neglected and turned a lot made them submit the assignments late, and another problem they faced.

\section{REFERENCES}

[1] Wijayanto, “Radar Surabaya,” 19 Juni, 2019. https://radarsurabaya.jawapos.com/read/2021/02/19 /242493/portofolio-nilai-rapor-dan-penilaian-sikapjadi-penentu-kelulusan (accessed Mar. 27, 2021).

[2] Asrul, R. Ananda, and Rosinta, Evaluasi Pembajalaran. 2014.

[3] Asrijanty, "Penilaian Portofolio 2019,” Penilai. Portofolio, 2019.

[4] C. A. Mertler, Classroom Assessment: A Practical Guide for Educators: EBSCOhost, 1st Editio. Routledge, 2017.

[5] S. Muenthaisong, D. Khampusaen, and J. Lao-un,

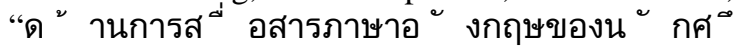
กษาพยาบาลศาสตรบั ณท ต Effects Of The Using Electronic Portfolio On Thai Efl Nursing Students ' Oral Communication,” vol. 2, pp. 41-55.

[6] Amirono and Daryanto, Evaluasi dan penilaian pembelajaran kurikulum 2013. Gava Media, 2016.

[7] T. Ana, Maria;Ndole2, "Efektivitas Penilaian 
Pembelajaran Matematika Selama Masa Pandemi Covid-19 Sdk Ndona 2 Kecamatan Ndona Kabupaten Ende,” JUPIKA J. Pendidik. Mat. Univ. Flores, vol. Volume 4, p. Hal. 82-91, 2021.

[8] I. F. Ahmad, “Asesmen Alternatif Dalam Pembelajaran Jarak Jauh Pada Masa Darurat Penyebaran Coronavirus Disease (Covid-19) Di Indonesia,” Pedagog. J. Pendidik., vol. 7, no. 1, pp. 195-222, 2020, doi: 10.33650/pjp.v7i1.1136.

[9] C. Hsu, "E-Portfolio as Final Assessment for a Graduate Online Course in Pandemic," vol. 4, no. 12, pp. 99-104, 2020. 